\section{RESEARCH ON THE SUSTAINABLE DEVELOPMENT OF PHYSICAL EDUCATION STUDENTS' EXERCISE IN COLLEGES AND UNIVERSITIES}

\author{
PESQUISA SOBRE O DESENVOLVIMENTO SUSTENTÁVEL DO EXERCÍCIO DE ESTUDANTES DE \\ EDUCAÇÃO FISICA EM FACULDADESE UNIVERSIDADES \\ INVESTIGACIÓN SOBRE EL DESARROLLO SOSTENIBLE DEL EJERCICIO DE ESTUDIANTES DE \\ EDUCACIÓN FISICA EN COLEGIOS Y UNIVERSIDADES
}

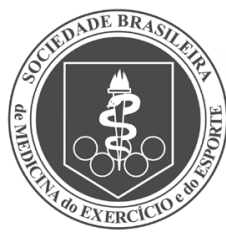

Original Article ARTIGo ORIGINAL Artículo Original

\begin{abstract}
Chaohu He1 (D)
(Physical Education Professional)

Zhenpeng Huang2 (ID)

(Physical Education Professional)

Liaokun Yel (DD

(Physical Education Professional)

1. School of Physical Education, Kunming University, Kunming, 650214, China.

2. School of Physical Education, Hanshan Normal University,

Chaozhou, 521041, China.
\end{abstract}

\section{Correspondence:}

Zhenpeng Huang Chaozhou

521041, China.

hssyhzp1974@126.com

\begin{abstract}
Introduction: The essence of sustainable development is ecological civilization. The entire modern development, including sports in colleges and universities, is built based on resource conservation, enhanced environmental support capabilities, and a virtuous ecological environment cycle to achieve sustainable economic and social development. Objective: Looking at the development history of sports in Chinese colleges and universities for more than 50 years, there have been many successful experiences in human resource development, and there are also many problems that need to be solved. Methods: The author took 442 people from 4 provinces as the survey object, researched and discussed the evaluation indicators of the sustainable development of sports in colleges and universities. After factor analysis and professional theoretical research, a total of 15 indicators in 5 categories were established: science and technology, moral education, system Standard category, economic, competitive development category, external input category, and the coach training system category that eliminates "inbreeding." Results: The author found in the research that both sports and non-sports families in China are unwilling to engage in sports and college sports for their children. The main reasons are traditional ideological issues, sports social status issues, and athletes' education issues. Among them, coaches, the "inbreeding"training system is one of the main reasons that affect the sports talent resources of colleges and universities in China. Conclusions: There can be at least five types of evaluation indicators for the sustainable development of sports in Chinese colleges and universities: science and technology and ethics education, institutional norms, economic and competitive development, external investment, and a coach training system that eliminates inbreeding. The income of sports families is generally lower than that of non-sports families, and their education level is also lower. Level of evidence Il; Therapeutic studies - investigation of treatment results.
\end{abstract}

Keywords: Sports; Sustainable development; Evaluation index; Workforce.

\section{RESUMO}

Antecedentes: A essência do desenvolvimento sustentável é a civilização ecológica Todo o desenvolvimento moderno, incluindo esportes universitários, ébaseado na economia de recursos, fortalecimento da capacidade de suporte ambiental e realização do desenvolvimento econômico e social sustentável do ciclo ecológico e ambiental. Objetivo: revisar o curso de desenvolvimento de educação física da universidade chinesa por mais de 50 anos, há muitas experiências bem-sucedidas no desenvolvimento de recursos humanos e muitos problemas a serem resolvidos. Métodos: 442 pessoas de 4 províncias foram investigadas para conhecer o índice de avaliação do desenvolvimento sustentável da educação física universitária. Por meio da análise fatorial e da pesquisa da teoria profissional, foram determinados 15 índices de cinco categorias principais: ciência e tecnologia, educação moral, normas institucionais, economia, desenvolvimento competitivo, insumos externos e eliminação da consanguinidade. Resultados: as famílias esportivas e não esportivas não estão dispostas a permitir que seus filhos participem de atividades esportivas universitárias, sendo os principais motivos as ideias tradicionais, o status social do esporte e a educação dos atletas. Entre eles, o sistema de treinamento "consanguíneo" de treinadores é um dos principais motivos que afetam os recursos de talentos esportivos das universidades chinesas. Conclusão: O índice de avaliação do desenvolvimento sustentável da educação física nas universidades chinesas pode ser dividido em pelo menos cinco categorias: educação científica e ética, normas institucionais, desenvolvimento econômico e competitivo, investimento externo, eliminação do sistema endógamo de treinamento de treinadores. A renda das famílias que praticam esportes é geralmente menor do que a das não praticantes, e o nível de educação também é baixo. Nível de evidência ll; Estudos terapêuticos: investigação dos resultados do tratamento.

Descritores: Esportes; Desenvolvimento sustentável; Índice de avaliação; Recursos humanos. 


\section{RESUMEN}

Antecedentes: la esencia del desarrollo sostenible es la civilización ecológica.Todo el desarrollo moderno, incluidos los deportes universitarios, se basa en el ahorro de recursos, el fortalecimiento de la capacidad de apoyo ambiental y la realización del desarrollo económico y social sostenible del ciclo ecológico y ambiental. Objetivo: revisar el curso de desarrollo de la educación física universitaria en China durante más de 50 años, hay muchas experiencias exitosas en el desarrollo de los recursos humanos, y hay muchos problemas que resolver. Métodos: 442 personas de 4 provincias fueron investigadas para conocerel índice de evaluación del desarrollo sostenible de la educación física universitaria. A través del análisis factorial y la investigación de la teoría profesional, se han determinado 15 índices de cinco categorías principales: ciencia y tecnología, educación moral, normas institucionales, economía, desarrollo competitivo, insumos externos y eliminación de la endogamia. Resultados: tanto las familias deportivas como las no deportivas no están dispuestas a que sus hijos participen en actividades deportivas universitarias. Las principales razones son las ideas tradicionales, la condición social deportiva y la educación de los atletas. Entre ellas, el sistema de formación de "endogamia" de los entrenadores es una de las principales razones que afectan a los recursos de talentos deportivos de las universidades chinas. Conclusión: el índice de evaluación del desarrollo sostenible de la educación física en las universidades de China puede dividirse en al menos cinco categorías: educación científica y ética, normas institucionales, desarrollo económico y competitivo, inversión externa, eliminación del sistema de formación de entrenadores endogámico. Los ingresos de las familias deportivas son generalmente inferiores a los de las familias no deportivas, y el nivel de educación también es bajo. Nivel de evidencia ll; Estudios terapéuticos: investigación de los resultados del tratamiento.

Descriptores: Deportes; Desarrollo sostenible; Indice de evaluación; Recursos humanos.

\section{INTRODUCTION}

The essence of sustainable development is an ecological civilization. The entire modern development, including sports and universities, is established based on resource conservation, enhanced environmental support, and a virtuous cycle of the ecological environment to achieve sustainable economic and social development. ${ }^{1}$ The sustainable development of sports in colleges and universities depends largely on the reasonable development and allocation of sports human resources in colleges and universities. The development of human resources for sports in colleges and universities mainly includes athletes, coaches, and generalized managers.

\section{THE GUIDING IDEOLOGY OF THE SUSTAINABLE DEVELOPMENT EVALUATION INDEX OF COMPETITIVE SPORTS}

\section{Reflecting on the idea of development}

Without development, there will be no improvement in people's living standards. The idea of sustainable development also emphasizes economic growth, social progress, and wealth accumulation, rather than avoiding development. Therefore, the assessment of the sustainable development of competitive sports must reflect the degree of development of competitive sports in a country or region, that is, be able to judge whether the level of competitive sports in a country or region is truly developing. ${ }^{2}$ The emphasis here is on the concept of "quantity," the overall competitive sports development level.

\section{Reflect on the idea of coordination}

That is, it can distinguish the development of competitive sports in a country or region and the problems of mass sports, school sports, leisure sports, etc. whether it is balanced, whether the development level of competitive sports is coordinated with the social economy, people's living standards, and scientific and technological strength, whether the market development of competitive sports is balanced with the government's macro-control. ${ }^{3-6}$

\section{Basic principles for the selection of evaluation indicators for the sustainable development of competitive sports}

The amount of information reflected in the sustainable development of competitive sports is very large and complex, and it covers a wide range of fields. Therefore, the determination of evaluation indicators is a very difficult task. It should pay attention to the basic requirements of the scientific development view. The selection of evaluation indicators must follow the scientific principle and pay attention to the effectiveness. ${ }^{6}$ The formulation of policies has a guiding role.

\section{Scientific principles}

The sustainable development index system of competitive sports must be established on a scientific basis, which can fully reflect the internal mechanism of the sustainable development of competitive sports. The indicators' meaning must be simple, clear, standard for measurement methods, and standardized statistical calculation methods, which can comprehensively and comprehensively reflect competitive sports.

\section{Dynamic principle}

Considering that competitive sports' sustainable development needs to be reflected through a certain time scale, the selection of evaluation indicators requires full consideration of the characteristics of dynamic changes and a better description, depiction, and measurement of the future development or development trend of competitive sports.

\section{Principle of Comparability}

The sustainable development system of competitive sports is a complex and huge system, which can be decomposed into several subsystems. Therefore, to describe and evaluate the degree of sustainable development and development of competitive sports, different indicators should be used at different levels. As far as possible, the evaluation indicators adopt common names, concepts, and calculation methods to facilitate horizontal and vertical comparisons. 


\section{Operability principle}

Decision-makers will ultimately use the index system for sustainable development of competitive sports to reflect the current situation and trends of competitive sports development and serve policy formulation and scientific management. Therefore, the evaluation index system's establishment must consider the principle of operability, that is, easy data Collection, easy to quantify, and evaluable.

\section{METHOD}

\section{Research objects}

The paper sent out questionnaires to 572 people in Jiangsu, Fujian, Jiangxi, and Anhui, and recovered 442 valid questionnaires, with an effective recovery rate of $77.3 \%$. The details of the research subjects are shown in Table 1.

Research subjects 250 women, 194 men, 321 non-sports families, and 121 sports families (a sports family means that at least one of the three generations of the family is engaged in sports work); 286 people have higher education (above college), 14 people have income More than 2000 yuan/month.

Table 1. The basic situation of research objects.

\begin{tabular}{c|c|c|c|c|c}
\hline Province & $\begin{array}{c}\text { Number of } \\
\text { people }\end{array}$ & Education & $\begin{array}{c}\text { Number of } \\
\text { people }\end{array}$ & $\begin{array}{c}\text { Monthly } \\
\text { income } \\
\text { (yuan) }\end{array}$ & $\begin{array}{c}\text { Number } \\
\text { of people }\end{array}$ \\
\hline Jiangsu & 138 & $\begin{array}{c}\text { junior high } \\
\text { school }\end{array}$ & 48 & $0-100$ & 20 \\
\hline Fujian & 137 & High school & 108 & $101-1000$ & 318 \\
\hline Anhui & 86 & Junior college & 188 & $1001-2000$ & 90 \\
\hline Jiangxi & 81 & $\begin{array}{c}\text { Bachelor } \\
\text { degree or } \\
\text { above }\end{array}$ & 98 & Above 2000 & 14 \\
\hline
\end{tabular}

\section{Research methods}

\section{Questionnaire survey method}

The questionnaire includes 60 questions in 3 categories. The first category is the basic situation of the research object; the second category is the evaluation of sports talent resources in Chinese colleges and universities; the third category is the evaluation index used to evaluate the sustainability of sports in Chinese colleges and universities. Evaluation of development.

\section{Mathematical Statistics}

The questionnaires of the first and second types of questionnaires are tested for differences between each group and each question, and the evaluation index analysis is carried out by R-type factor analysis. All statistical analysis results are obtained under the SPSS statistical program.

\section{Establish a judgment matrix}

The judgment matrix is the basic information of the analytic hierarchy process, and it is also an important basis for calculating the relative importance. The judgment matrix is a certain element $H_{S}$ of the upper level as the judgment criterion, and the elements of this level are compared to determine the matrix elements. Assuming that the evaluation target is $A$ and the evaluation index set is $B=\left\{a_{1}, a_{2}, . ., a_{n}\right\}$, the construction of the judgment matrix $P(A-B)$ is:

$$
P=\left[\begin{array}{cccc}
a_{11} & a_{12} & \ldots & a_{1 n} \\
a_{21} & a_{22} & \ldots & a_{2 n} \\
\ldots & \ldots & \ldots & \ldots \\
a_{n 1} & a_{n 2} & \ldots & a_{n m}
\end{array}\right]
$$

\section{Calculate the judgment matrix}

When applying the analytic hierarchy process to make multi-objective decision-making, you need to know the relative importance of $a_{i}$ to $H_{S}$, that is, the weight of $a_{i}$ to $H_{S}$. For this reason, the eigenvector $W$ of the relevant judgment matrix can be obtained first, and then after normalization $a_{i}$, the relative importance to $H_{S}$, that is, the weight, can be obtained. Therefore, the method of calculating the component $W_{i}$ of the feature vector $W$ is as follows:

$$
W_{i}=\left(\mathbb{1}_{j=1}^{2} a_{i j}\right)^{1 / n}, i=,, \ldots, n
$$

Normalize the vector $W=\left\{W_{1}, W_{2}, \ldots, W_{n}\right\}^{T}$, according to the formula

$$
W_{i}^{0}=\frac{W_{i}}{\hat{O}_{i=1}^{n} W_{i}}
$$

We calculate $W_{i}^{0}$ separately and get the feature vector

$$
W=\left\{W_{1}^{0}, W_{2}^{0}, W_{3}^{0}, W_{4}^{0}\right\}
$$

Calculate the largest characteristic root $\ddot{e}_{\max }$ of the judgment matrix.

$$
\ddot{e}_{\max } \dot{\Theta}_{i=1}^{n} \frac{(A W)_{i}}{n W_{i}^{0}}
$$

Among them, $(A W)_{i}$ represents the i element of vector $A W$

\section{RESULTS}

\section{Educational level and income of different families}

It can be seen from Table 2 that the educational level and income of non-sports families are higher than those of sports families. The level of education is the internal condition for the formation of good professional ethics, and the institutional norms are the external conditions for the formation of good professional ethics.

\section{People's attitudes towards sports in colleges and universities}

People's attitudes towards sports in colleges and universities (Table 3 and 4). With the further establishment of Chinese market economy system, the development of sports in colleges and universities will also balance the input and output of sports personnel in colleges and universities.

\section{Attitudes of different income groups towards sports in colleges and universities}

It can be seen from the questionnaire that there are four main reasons: one is the status issue. $22.6 \%$ of the families who do not want their children to engage in sports training think that the income of

Table 2. Educational level and income of different family research objects.

\begin{tabular}{c|c|c|c|c|c|c|c}
\hline & \multicolumn{4}{|c|}{ Education } & \multicolumn{3}{c}{ Monthly income } \\
\cline { 2 - 8 } & $\begin{array}{c}\text { junior } \\
\text { high } \\
\text { school }\end{array}$ & $\begin{array}{c}\text { High } \\
\text { school }\end{array}$ & $\begin{array}{c}\text { Junior } \\
\text { college }\end{array}$ & $\begin{array}{c}\text { Bachelor } \\
\text { degree or } \\
\text { above }\end{array}$ & $\begin{array}{c}\text { High } \\
\text { income }\end{array}$ & $\begin{array}{c}\text { Middle } \\
\text { income }\end{array}$ & $\begin{array}{c}\text { Low } \\
\text { income }\end{array}$ \\
\hline $\begin{array}{c}\text { Non-sports } \\
\text { family }\end{array}$ & 18 & 98 & 123 & 82 & 16 & 245 & 60 \\
\hline $\begin{array}{c}\text { Sports } \\
\text { family }\end{array}$ & 30 & 30 & 65 & 16 & 1 & 95 & 25 \\
\hline
\end{tabular}


sports work is low, 48.0\% think that there is little way out, and 24.9 think that the status is low is the problem of coaches. 31.9\% believed that the coaches' literacy level, 32.6\% thought that the coaches were not very professional, $32.1 \%$ thought that the use of drugs, $44.8 \%$ thought that the coaches were eager for quick success, $56.1 \%$ thought that the success rate was low; the third was ideological problems. $17.9 \%$ believe that traditional thinking is affected, $20.1 \%$ believe that family income is low, and 27.1 families are afraid of their children's hardship. It is worth noting that $64.3 \%$ of families are afraid of affecting their children's cultural studies. This has raised the issue of Chinese youth in the sports sector in colleges and universities. The reorientation of the direction of sports schools; the fourth is the problem of colleges and universities' sports system. 33.7\% think that the system is unreasonable, and 29.0\% think that the competitive team atmosphere is unhealthy. (Table 5 and 6 )

Table 3. Parents' attitude towards their children's sports training (\%).

\begin{tabular}{c|c|c|c|c|c|c}
\hline & \multicolumn{3}{|c|}{ Only child } & \multicolumn{3}{c}{ Non-only child } \\
\hline & willing & Unwilling & $\begin{array}{c}\text { Very } \\
\text { unwilling }\end{array}$ & willing & Unwilling & $\begin{array}{c}\text { Very } \\
\text { unwilling }\end{array}$ \\
\hline $\begin{array}{c}\text { Sports family } \\
\begin{array}{c}\text { Non-sports } \\
\text { family }\end{array}\end{array}$ & 16 & 48.2 & 24.4 & 12.1 & 44.1 & 26.3 \\
\hline
\end{tabular}

Table 4. Parents' attitude towards their children's professional sports training (\%).

\begin{tabular}{c|c|c|c|c|c|c}
\hline & \multicolumn{3}{|c|}{ Only child } & \multicolumn{3}{c}{ Non-only child } \\
\hline & willing & Unwilling & $\begin{array}{c}\text { Very } \\
\text { unwilling }\end{array}$ & willing & Unwilling & $\begin{array}{c}\text { Very } \\
\text { unwilling }\end{array}$ \\
\hline Sports family & 32.2 & 17.4 & 25.9 & 18.4 & 36.6 & 31.6 \\
\hline $\begin{array}{c}\text { Non-sports } \\
\text { family }\end{array}$ & 37.3 & 11.5 & 25.9 & 25.6 & 32 & 28.7 \\
\hline
\end{tabular}

Table 5. Attitudes of families with different incomes to their children's sports training\%.

\begin{tabular}{c|c|c|c|c|c|c}
\hline & \multicolumn{2}{|l|}{ High-income family } & \multicolumn{2}{c|}{$\begin{array}{c}\text { Middle-income } \\
\text { family }\end{array}$} & \multicolumn{2}{l}{ low-income family } \\
\hline & willing & Unwilling & willing & Unwilling & willing & Unwilling \\
\hline $\begin{array}{c}\text { Sports Training } \\
\text { Professional } \\
\text { sports }\end{array}$ & 22.2 & 77.8 & 25.4 & 74.6 & 30.2 & 69.8 \\
\hline
\end{tabular}

Table 6. Factor analysis results.

\begin{tabular}{|c|c|c|c|c|c|}
\hline Main factor & First factor & $\begin{array}{l}\text { Second } \\
\text { factor }\end{array}$ & Third factor & $\begin{array}{l}\text { Fourth } \\
\text { factor }\end{array}$ & Fifth factor \\
\hline Factor name & $\begin{array}{l}\text { Science } \\
\text { and Ethics } \\
\text { Education }\end{array}$ & $\begin{array}{c}\text { Institutional } \\
\text { norms }\end{array}$ & \begin{tabular}{|c|} 
Economic, \\
competitive \\
development \\
\end{tabular} & $\begin{array}{l}\text { External } \\
\text { input }\end{array}$ & $\begin{array}{l}\text { Eliminate } \\
\text { inbreeding }\end{array}$ \\
\hline \multirow{3}{*}{$\begin{array}{l}\text { High load } \\
\text { factor }\end{array}$} & Q57, Q59 & Q55, Q47 & Q42, Q43 & \multirow{3}{*}{ Q39, Q40 } & \multirow{3}{*}{ Q49, Q41 } \\
\hline & Q56, Q52 & Q46, Q54 & \multirow{2}{*}{ Q44, Q45 } & & \\
\hline & Q48, Q50 & Q51, Q53 & & & \\
\hline $\begin{array}{c}\text { Contribution } \\
\text { rate }(\%)\end{array}$ & 47.9 & 7.7 & 5.1 & 4.1 & 3.7 \\
\hline
\end{tabular}

\section{DISCUSSION}

\section{The relationship between people's attitudes towards sports in colleges and universities and human resources}

It can be seen from the questionnaire that there are four main reasons: one is the status issue. $22.6 \%$ of the families who do not want their children to engage in sports training think that the income of sports work is low, 48.0\% think that there is little way out, and 24.9 think that the status is low is the problem of coaches. $31.9 \%$ believed that the coaches' literacy level, $32.6 \%$ thought that the coaches were not very professional, $32.1 \%$ thought that the use of drugs, $44.8 \%$ thought that the coaches were eager for quick success, $56.1 \%$ thought that the success rate was low; the third was ideological problems. $17.9 \%$ believe that traditional thinking is affected, $20.1 \%$ believe that family income is low, and 27.1 families fear their children's hardship. It is worth noting that $64.3 \%$ of families are afraid of affecting their children's cultural studies. This has raised the issue of Chinese youth in the sports sector in colleges and universities. The reorientation of the direction of sports schools; the fourth is the problem of colleges and universities' sports system. $33.7 \%$ think that the system is unreasonable, and $29.0 \%$ think that the competitive team atmosphere is unhealthy.

\section{CONCLUSION}

There can be at least five types of evaluation indicators for the sustainable development of sports in colleges and universities in China: science and technology and ethics education, institutional norms, economic sports development, external investment, and a coach training system that eliminates inbreeding. (2) The income of sports families is generally lower than that of non-sports families, and their education level is also lower. The stock of human capital and human resources of sports in colleges and universities in our country is low. Whether it is sports or non-sports families, there is a tendency that children are unwilling to engage in sports in colleges and universities. Within the scope of this research, one of the main factors affecting the stock of human capital and human resources of sports in colleges and universities in China is coaches, especially the training system and system of coaches. Chinese traditional thinking is also one of the main factors affecting the human capital and human resource stock of sports in Chinese colleges and universities, especially only-child families' performance.

\section{ACKNOWLEDGMENTS}

The work was supported by Blue book of campus development in Yunnan Province(Grant: 2017XYZQ02).

All authors declare no potential conflict of interest related to this article

AUTHORS' CONTRIBUTIONS: Each author has made significant personal contributions to the manuscript. Chaohu He analyzed and explained the relevant data of the sustainable development of physical education students in colleges and universities, and played a leading role in writing the full text. Zhenpeng Huang made major contributions to the research background and the collection of research literature and was the main contributor to the manuscript writing. Liaokun Ye made a great contribution to the questionnaire survey. All authors read and approved the final manuscript.

\section{REFERENCES}

1. Clutterbuck R, Doherty A. Organizational capacity for domestic sport for development. Journal of Sport for Development. 2019;7(12): 16-32.

2. Leta B, Kebede O. Journal of Equity in Science and Sustainable Development. Journal of Equity in Science and Sustainable Development. 2019;3(1): 29-38

3. Abebe A. The key challenges of youth in Ethiopia. J Agric Econ. 2020;6(1): 684-88.
4. Lindsey I, Darby P. Sport and the Sustainable Development Goals: Where is the policy coherence. Int Rev Sociol Sport. 2019;54(7):793-812.

5. Hoekman MJ, Schulenkorf N, Peachey JW. Re-engaging local youth for sustainable sport-for-development. Sport Management Review. 2019;22(5):613-25.

6. Whitley MA, Farrell K, Wolff EA, Hillyer SJ. Sport for development and peace: Surveying actors in the field. J Sport Dev. 2019;7(11):1-15. 